JOURNAL OF AGRICULTURE AND APPLIED BIOLOGY

2020, Vol. 1, No. 2, $92-99$

http://dx.doi.org/10.11594/jaab.01.02.07

Research Article

\title{
In vitro assessment of protease production and stress tolerance of mutant isolates of Trichoderma sp.
}

\author{
Çiğdem Küçük1*, Tülay Gezer² \\ ${ }^{1}$ Harran University, Science and Art Faculty, Department of Biology, Şanlıurfa, Turkey, \\ ${ }^{2}$ Harran University, School of Natural and Applied Sciences, Şanlıurfa, Turkey,
}

Article history:

Submitted 27 August 2020

Accepted 21 September 2020

Published 28 December 2020

Keywords:

Abiotic stress factors

Mutant isolate

Protease

Trichoderma sp.,

*Corresponding author:

E-mail:

ckucuk@harran.edu.tr

\begin{abstract}
Soil-borne plant pathogenic fungi cause serious losses in agricultural products. The antagonistic fungi for the control of plant diseases have increased efficiency and use of space has emerged as an alternative to other methods for the protection of agricultural products. One of the fungi used for this purpose is Trichoderma species. In this study mutant isolates of Trichoderma spp. were used. The resistance and protease enzyme activities of mutant isolates against abiotic factors such as temperature, drought and salinity were investigated. Mutant isolates of Trichoderma sp. were showed differed in tolerance to different abiotic stress factors. Protease enzyme activity produced by isolates was influenced by the tested abiotic factors. In the medium containing 30\% PEG, the highest protease activity was determined in Tm13 isolate. Indigenous Trichoderma strains produced proteases in high temperature, drought and saline conditions. This indicates that isolates may be promising candidates in agricultural production.
\end{abstract}

\section{Introduction}

The use of chemical pesticides is very common among methods used to protect agricultural products from diseases. Fungicides and fumigants are used more than herbicides and insecticides in agricultural production (Ghanbarzadeh et al., 2014; Reetha et al., 2014; Schmoll, 2010). In 1969, the morphological characteristics of Trichoderma were divided into 9 genotypes; T. harzianum Rifaii, T. viride, T. hamatum (Bonord.) Bainier, T. koningii (Oudem.) Duche R. Helim, T. polysporum (Link) Rifaii, T. piluliferum J. Webster Rifaii, T. aureoviride Rifaii, T. longibrachiatum Rifaii ve T. pseudokoningii Rifaii (Btaszcyk ve ark, 2014). The research has focused on the identification of isolates resistant to high temperature and high salt concentration (Poosapati et al., 2014). Trichoderma isolates tolerated to drought and high temperature were identified from hot soils (Poosapati et al., 2014). In one study, temperature tolerant Trichoderma isolates were identified. Such isolates have been shown to be antagonistic to pathogenic microorganisms, which are resistant to temperature fluctuations caused by global warming (Poosapati et al., 2014). Ferre and Santamarina (2010) reported that temperature and water activity were effective in T. harzianum antagonism. 
Karmel-Reetha et al. (2014) and Mohammed and Haggag (2006) found that T. harzianum mutant isolates produced higher levels of chitinase, cellulase, B-gluconase enzymes under salt stress conditions than non-mutant isolates. The researchers reported that mutant isolates showed growth and formed spores in medium containing $69 \mathrm{mM} \mathrm{NaCl}$.

The isolates mutanted with UV rays were found to have higher sporulation abilities with the survival time to the soil than the natural isolates. It has been reported that Trichoderma mutant isolates have inhibited the diseases caused by Pythium aphanidermatum and Sclerotium rolfsii in tobacco, M. phaseolina in sunflower (Rao et al., 2015; Reetha et al., 2014). These isolates were found to be more successful than natural isolates in preventing the growth of Sclerotium sp., agent of white root rot disease (Mukherjee and Raghu, 1997; Qualhato et al., 2013; Rao et al., 2015). Szekeres et al. (2004) found that the ultraviolet-exposed Trichoderma harzianum T334 isolate increased the biocontrol activity, while the mutant isolate secreted a high amount of protease enzyme compared to the non-mutant. Rey et al. (2001) found that the mutant isolate of Trichoderma harzianum was effective in inhibiting the growth of Botrytis cinerea. T. harzianum mutant isolate produced four times more enzymes, and it was highly inhibited by the pathogen growth (Rey et al., 2001; Qualhato et al., 2013).

Trichoderma species have been reported to be the best protease producers (Alamri et al., 2015; Gajera and Vakharia, 2012; Kumari et al., 2012). Extracellular protease production potentials of Trichoderma isolates have been investigated. Researchers have found that the produced protease is altered by isolation (Szekeres et al., 2004).

Successful biological control is achieved with antagonistic microorganisms that reduce the activity of plant pathogens (Rao et al., 2015). Antagonistic property of Trichoderma spp., which involves direct micoparasitism involving the production of enzymes that break down the cell wall of the pathogenic fungus (Lorito et al., 2010; Qualhato et al., 2013).

The mutant isolates of Trichoderma related studies in Turkey is far from each other and quite a few. Importance of organic agriculture and environmental health issues brought the preparations prepared from microorganisms to the agenda. For this purpose, in our study, mutant isolates were obtained by exposure to ultraviolet light 18 isolate of Trichoderma sp. previously isolated from in field soil Şanlıurfa, Turkey.

\section{Materials and Methods}

Isolates were taken from Harran University, Microbiology laboratory. All isolates were stored in Potato Dextrose Agar (PDA) at $4{ }^{\circ} \mathrm{C}$.

\section{Resistance to abiotic stress conditions of iso- lates}

Resistance of the isolates to different stress conditions (temperature, salinity, drought) were investigated. To determine the tolerance to temperature; $5 \mathrm{~mm}$ discs from cultures (48 hours) were inoculated into the PDA medium and incubated at $25,30,35,45$ and $50^{\circ} \mathrm{C}$ for 5 days (Mukherjee and Raghu 1997). To determine salt tolerance; 70, 150, 240, 300 and 350 $\mathrm{mM} \mathrm{NaCl}$ were added to the PDA medium, 5 $\mathrm{mm}$ diameter discs of the isolates were inoculated into the media and incubated for 5 days at $30^{\circ} \mathrm{C}$ (Abdel-Latif et al., 2005). To determine tolerance to drought; $10,20,30,35$ and $40 \%$ polyethylene glycol (PEG, $6000 \mathrm{Da}$ ) was added separately to the PDA medium. The prepared media were autoclaved. Petri is poured into boxes. The $5 \mathrm{~mm}$ diameter discs of the isolates were inoculated and incubated for 5 days at 30 ${ }^{\circ} \mathrm{C}$ (Amalraj et al., 2011). In all experiments, the mycelial growth of isolates was measured and the effect of stress factors was determined.

\section{Protease production of isolates}

Azocasein prepared with $50 \mathrm{mM}$ Tris $\mathrm{HCl}$ (pH 8.1) was added onto $3 \mathrm{~mm}$ disks of the isolates on the PDA medium. The content was incubated for 1 hour at $27^{\circ} \mathrm{C}$. At the end of incubation, $300 \mu \mathrm{l}$ of trichloroacetic acid $(10 \% \mathrm{w}$ $\mathrm{v}^{-1}$ ) was added and the reaction was terminated (Lopez-Mondejar et al., 2011). The contents were centrifuged at $15000 \mathrm{~g}$ for 10 minutes. Supernatant $(350 \mu \mathrm{l})$ and $1 \mathrm{M} \mathrm{NaOH}(300 \mu \mathrm{l})$ were mixed and the centrifuged at $15000 \mathrm{~g}$ for 10 minutes. The content was measured at $440 \mathrm{~nm}$ against the standard (Gajera and Vakharia, 
2012). Protease activity was calculated as $\mathrm{U} \mathrm{ml}{ }^{-1}$. The experiment was done in 3 replicates.

\section{Protein measurement}

Protein measurement was performed according to the Coomassie brilliant blue G-250 method (Bradford, 1976). To determine the effect of temperature, salinity and drought on the enzyme; the best growth values of the isolates were selected.s

\section{Results and Discussion}

In our study, the resistance of our isolates to $\mathrm{NaCl}$ at different concentrations was investi- gated. Isolates were developed in medium containing $70 \mathrm{mM} \mathrm{NaCl}$. In the medium containing $240 \mathrm{mM} \mathrm{NaCl}$; the growth of Tm14 isolate was reduced by $28.5 \%$, Tm15 was reduced by $45.1 \%, \operatorname{Tm} 16$ isolate was reduced by $16.8 \%$ and $\mathrm{Tm} 18$ was reduced by $15.3 \%$. Tm5, Tm8, Tm11, Tm13 and Tm17 isolates were not affected from $240 \mathrm{mM} \mathrm{NaCl}$. In the medium containing $300 \mathrm{mM} \mathrm{NaCl}$; was determined to be the most inhibited Tm7 (246.1\%) isolate, this was followed by $\mathrm{Tm} 17$ (172.7\%) and $\mathrm{Tm} 15$ (114.3\%). Tm8 was observed as the most resistant isolate to $300 \mathrm{mM} \mathrm{NaCl}$ (Figure 1).

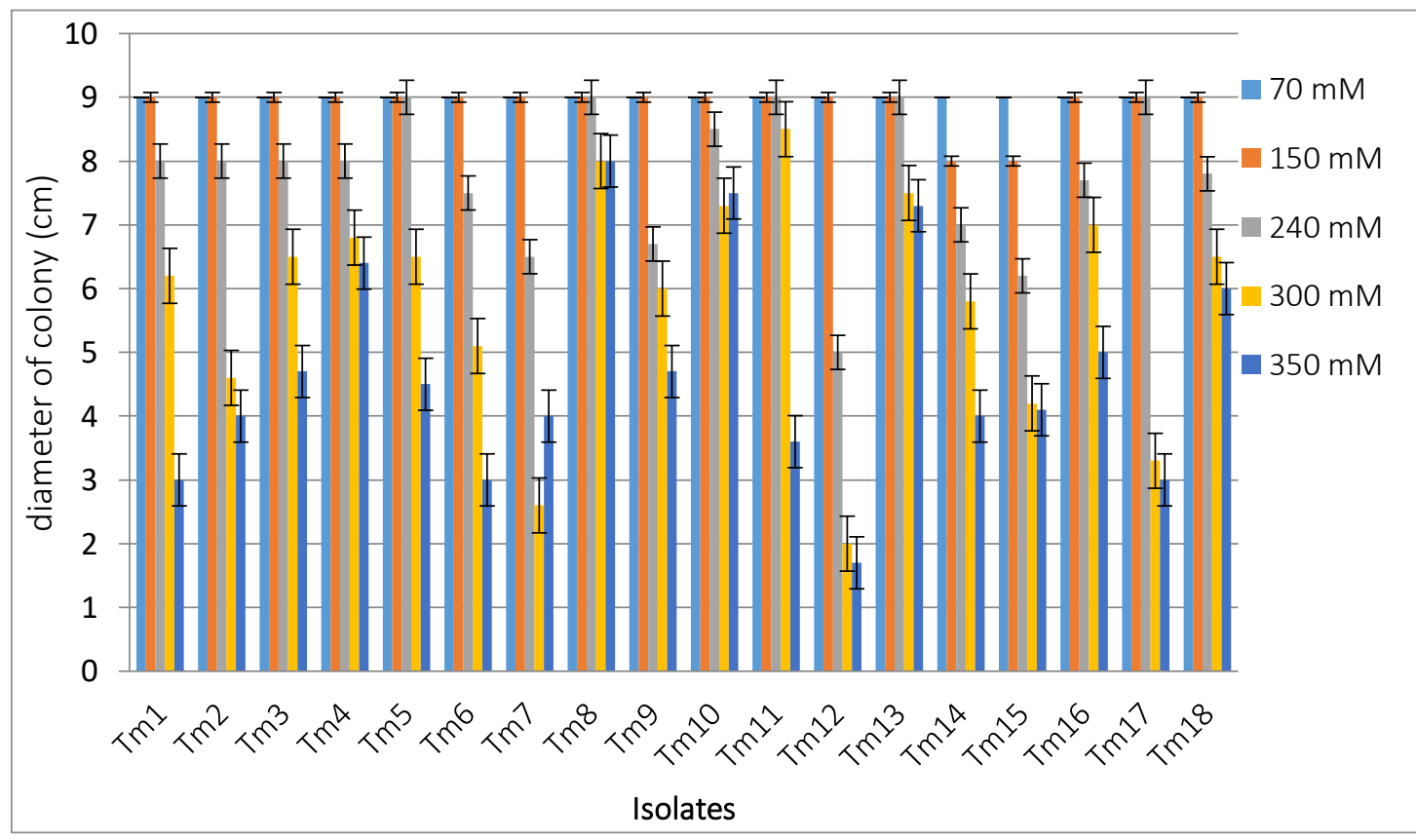

Figure 1. Tolerances of isolates to different concentrations of $\mathrm{NaCl}$

In the medium containing $350 \mathrm{mM} \mathrm{NaCl}$, the most resistant isolate was Tm8 (Figure 1) and the most sensitive isolate was identified as Tm12 (Figure 1). Mohammed and Haggag (2006) found that Trichoderma harzianum mutant isolates produced spores rapidly in medium containing $69 \mathrm{mM} \mathrm{NaCl}$ and T. harzianum mutant isolates produced gliotoxin, gliovirin and trichodermine antibiotics under salt stress. Researchers have also found that mutant isolates are also resistant to salt stress; chitinase, cellulase and ß-galactosidase enzyme activities are producers. The rapid micelle formation of our isolates in media containing $70 \mathrm{mM}$ and $150 \mathrm{mM} \mathrm{NaCl}$ is similar to the findings of researchers. Regraui and Lahlou (2005) reported that salinity was the most important environmental factor limiting the antagonistic activity of Trichoderma species. In our study, it was determined that mycelial growth of isolates were not affected at $25^{\circ} \mathrm{C}, 30^{\circ} \mathrm{C}$, and $35^{\circ} \mathrm{C}$ (Figure 2). All isolates grew at $45{ }^{\circ} \mathrm{C}$. The colony growths of the isolates were decreased at $50^{\circ} \mathrm{C}$. The isolates most affected by temperature at 50 ${ }^{\circ} \mathrm{C}$ are $\operatorname{Tm} 1, \operatorname{Tm} 10, \operatorname{Tm} 13, \operatorname{Tm} 4, \operatorname{Tm} 11, \operatorname{Tm} 8$, Tm6 and Tm17, respectively (Figure 2). 


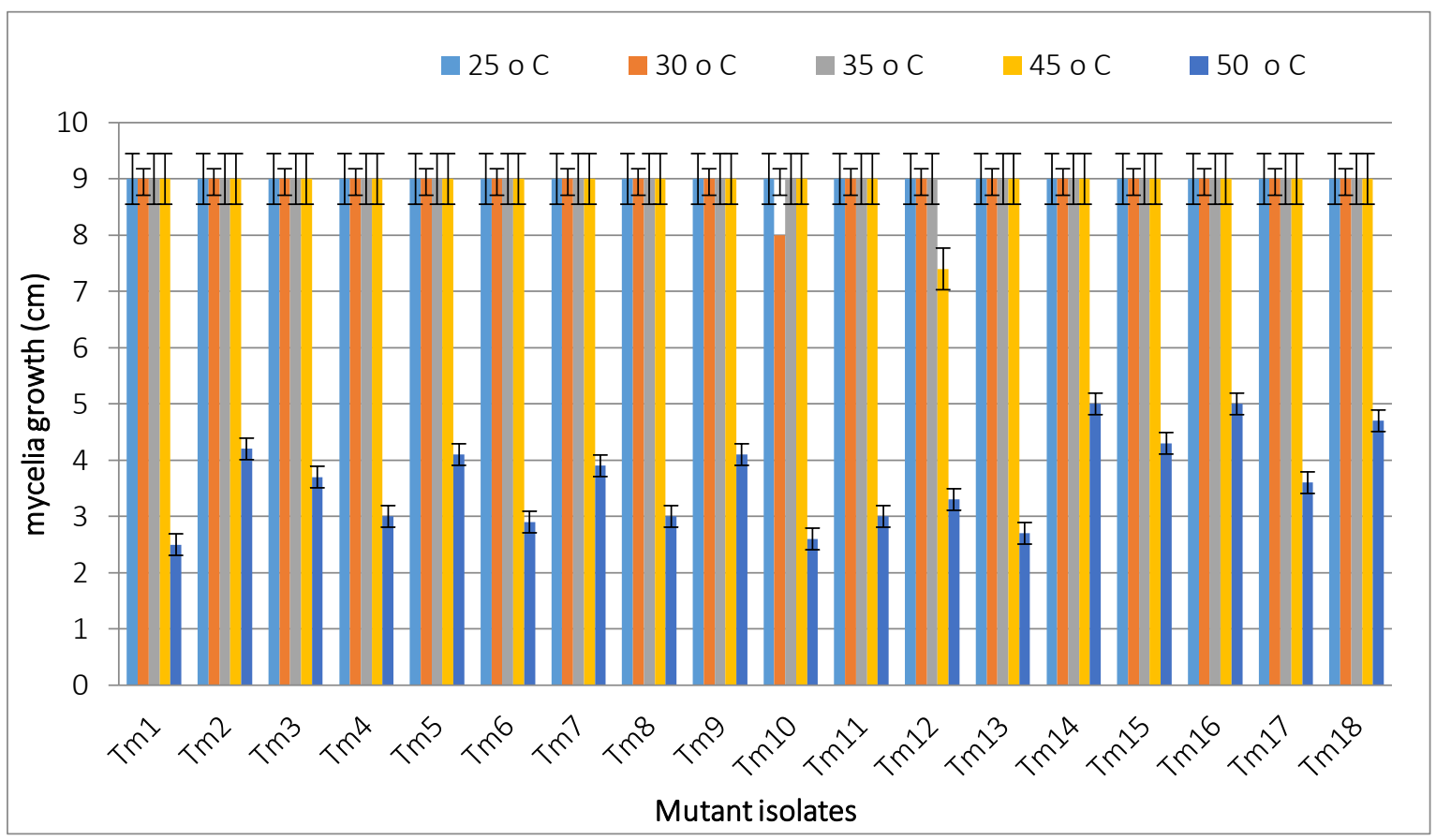

Figure 2. Tolerance of isolates to different temperatures

Nikolajeva et al. (2012) found that the effect of temperature on the growth of different Trichoderma isolates is important. It has been reported that T. polysporum is a psychrophile Trichoderma species (Begoude et al., 2007) and T. polysporum has been shown to growth rapidly at $4{ }^{\circ} \mathrm{C}$ (Nikolajeva et al., 2012). In our study, our isolates grew rapidly at $30,35{ }^{\circ} \mathrm{C}, 45$ ${ }^{\circ} \mathrm{C}$ (Figure 2). They grewn at $50^{\circ} \mathrm{C}$. Since our region has hot climates, isolates are isolated from agricultural fields in Şanliurfa, Turkey and therefore our isolates are adhered to high temperature and tested high temperature values are considered to be tolerant.

Amalraj et al. (2010) reported that the optimal temperature for the growth of isolates of Trichoderma asperellum is $30{ }^{\circ} \mathrm{C}$. Similar results have been reported in other Trichoderma species (Begoude et al., 2007). Mukherjee and Raghu (1997) investigated that the biocontrol effect of Trichoderma spp. on Sclerotium rolfsii and Trichoderma spp. was showed the optimum activity at $25-30{ }^{\circ} \mathrm{C}$. Begoude et al. (2007) reported that the optimal temperature for the growth of Trichoderma asperellum is $30{ }^{\circ} \mathrm{C}$. In our work, the tested temperature values temperatures $\left(25^{\circ} \mathrm{C}, 30^{\circ} \mathrm{C}, 35^{\circ} \mathrm{C}\right.$, and $\left.45^{\circ} \mathrm{C}\right)$ did not limit the growth of our isolates. The rapid growth of our isolates was at $25^{\circ} \mathrm{C}$ and $30{ }^{\circ} \mathrm{C}$ and this data is also supported by researchers' work. At $50^{\circ} \mathrm{C}$, our isolates produced micelles, but the formation of spores was reduced (Figure 2). Poosapati et al. (2014) observed that the growth of Trichoderma isolates did not have a negative effect in $35^{\circ} \mathrm{C}$. In our study, all of our isolates showed growth at $35^{\circ} \mathrm{C}$. Poosapati et al. (2014)'s work supports our work.

One of the most important limiting factors in the growth of Trichoderma species used as biofungicides has been described as drought (Amalraj et al., 2010; Mishra et al., 2016). It has been reported that the amount of water present in the environment and substrate in medium is very important for fungal growth (Begoude et al., 2007). Begoude et al. (2007) found that Trichoderma asperellum was resistant to drought. Tm 2 and Tm 13 from our isolates were found to be resistant to all tested drought conditions. Mycelial growths of Tm2 and Tm13 isolates decreased at increasing PEG concentration. Trichoderma species have been used as potential biocontrol agents against agricultural pathogens since the last 20-30 years.

Qualhato et al. (2013) reported that extracellular enzyme systems important for competition and mycoparasitism and produced by 
Trichoderma isolates are active even in conditions not suitable for mycelial growth. There are many mechanisms involved in Trichoderma antagonism. In mycoparasitism; Trichoderma sp. isolates directly inhibited the growth of plant pathogen by secreting lytic enzymes such as chitinase, B-1,3-gluconase and protease (Mendoza et al., 2015). Since cell walls of pathogenic fungi contain chitin, glucan and pro- teins, enzymes secreted in the presence of successful antagonist play an important role in the degradation of the cell wall of the pathogen (Lorito et al., 2010). Filamentous fungal cell walls were contain lipids and proteins. Thus, the protease synthesized by the antagonist fungus has been shown to destroy the host cell fungal pathogen (Lorito et al. 2010; Srivastova et al., 2015).

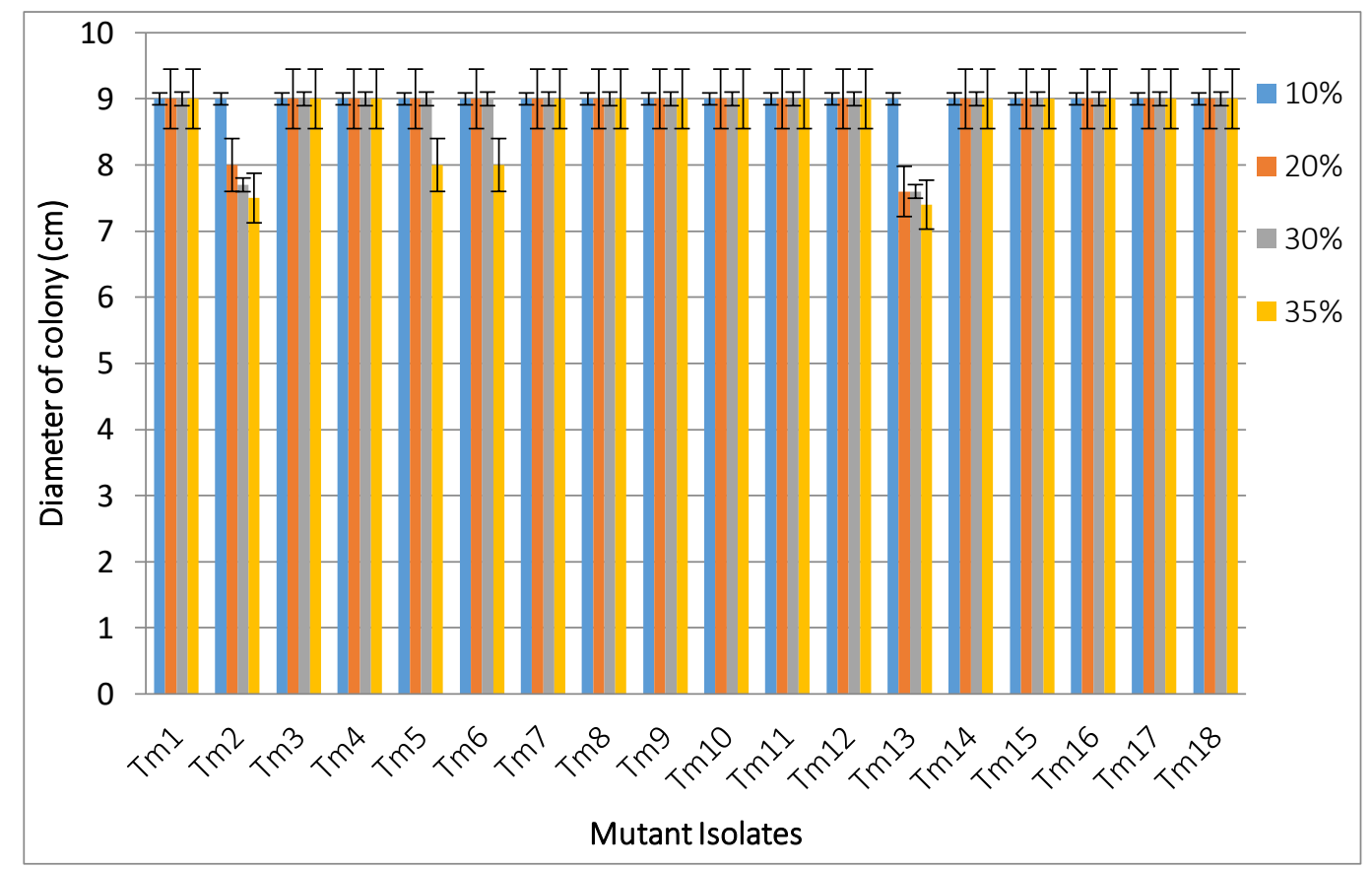

Figure 3. Tolerances of isolates to different PEG concentrations (drought)

Protease activities have been investigated taking into account stress factors that our isolates have best growth. Since all isolates showed growth at $240 \mathrm{mM} \mathrm{NaCl}, 30 \%$ PEG and $45^{\circ} \mathrm{C}$, protease activity was also examined at these values. Protease activities were investigated growth in media containing $240 \mathrm{mM}$ $\mathrm{NaCl}, 30 \%$ PEG and $45{ }^{\circ} \mathrm{C}$, respectively. The highest protease activity was obtained from the Tm15 isolate $\left(74 \mathrm{U} \mathrm{ml}^{-1}\right)$. This was followed by isolates Tm16 (35.8 $\left.\mathrm{U} \mathrm{ml}^{-1}\right)$ and $\operatorname{Tm} 17(28 \mathrm{U}$ $\mathrm{ml}^{-1}$ ). The protease activity produced by the isolates varied between $12.8-74 \mathrm{U} \mathrm{ml}^{-1}$. The lowest activity was examined in the Tm9 isolate (Figure 3). In the salt-containing medium, the protease activity produced by the isolates varies according to isolation. The \% reduction in protease activity when compared to control was observed in Tm5 isolate. Tm5 isolates were followed by $\mathrm{Tm} 16, \mathrm{Tm} 3$, and $\mathrm{Tm} 2$ isolates, respectively. 


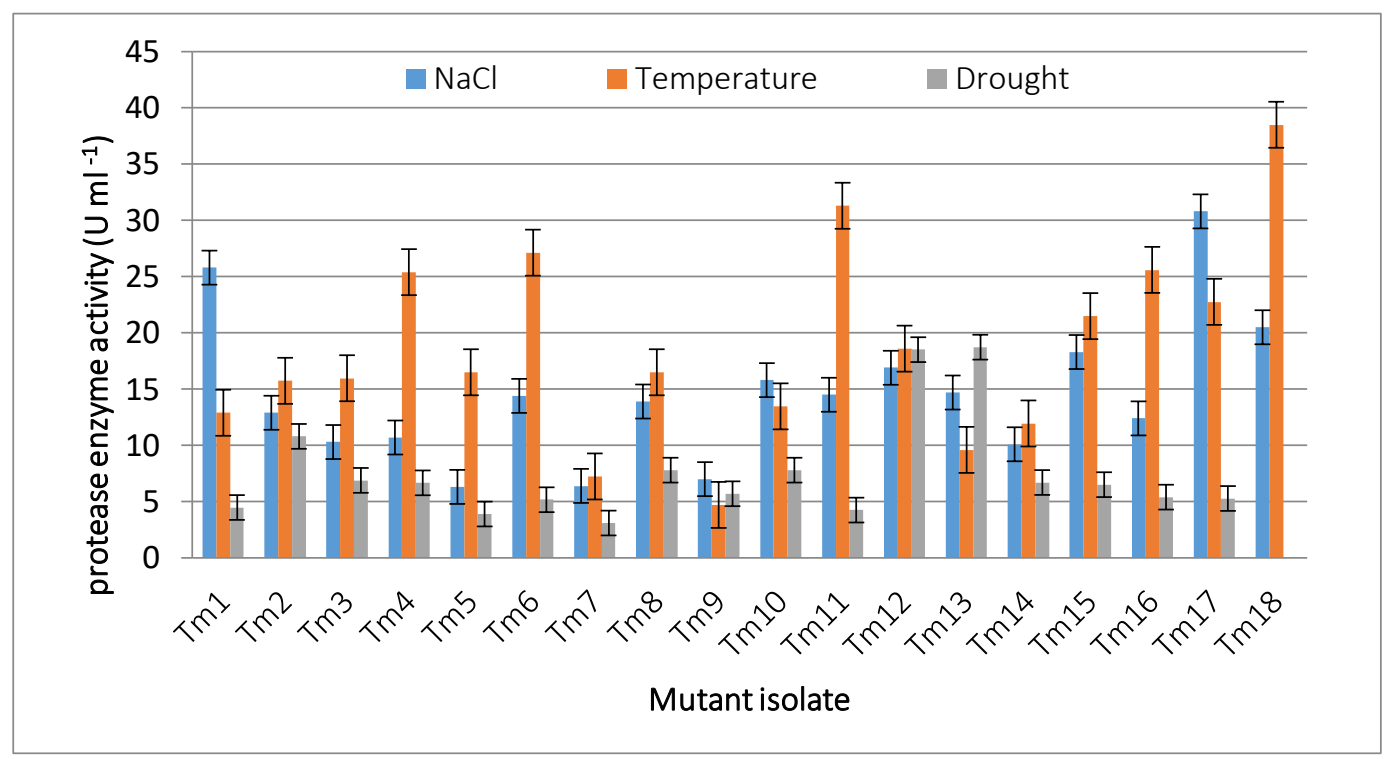

Figure 4. Protease activity of mutant isolates in different stress conditions

When $30 \%$ PEG was added to the medium, the protease activity produced by the isolates varied between 3.1-18.73 $\mathrm{U} \mathrm{ml}^{-1}$. The highest activity was taken from the Tm13 isolate under conditions where the drought was applied (Figure 4). Compared to control, the protease activity was decreased in $\operatorname{Tm} 15, \operatorname{Tm} 16, \operatorname{Tm} 10$, $\mathrm{Tm} 1$ and Tm5 isolates, respectively. When compared with control, Tm12 isolates were least affected by stress factors. In our study where heat is applied as a stress factor; the protease activity produced by the isolates ranged from 4.71 to $38.5 \mathrm{U} \mathrm{ml}^{-1}$ (Figure 4). Nikolajeva et al. (2012) investigated that the effects of different temperature values on protease activity produced by Trichoderma harzianum performed. Investigators have demonstrated that the optimal temperature for the highest protease activity secreted by $T$. harzianum is $30-40$ ${ }^{\circ} \mathrm{C}$ and the highest protease activity secreted by T. flavus is examined at $20-40{ }^{\circ} \mathrm{C}$. The same investigators have found that the growth of $\mathrm{Bo}$ trytis cinerea in the pod leaves is inhibited by the protease enzyme secreted by $T$. flavus and T. harzianum.

In the study of the temperature effect, the highest protease activity was taken from the Tm18 isolate, while the lowest activity was determined in the Tm9 isolate (Figure 4). When compared to control, the maximum \% decrease in protease activity was determined at $\mathrm{Tm} 15$ and $\mathrm{Tm} 10$, respectively. Compared to control in protease production, $\mathrm{Tm} 4$ is least affected by temperature. Different responses of the isolates to the applied stress factors can be thought of as different isolates.

\section{Conclusion}

As a result mutant isolates tested in our study were identified as potential isolates of abiotic stress factors. For Sanlıurfa, Turkey and similar climatic regions, farmers can be an economically viable alternative to disease control. Additional work needs to be done to assess our isolates for the protection of agricultural crops in high temperature, drought and salty soils. The rapid growth of our isolates, their ability to produce protease enzyme in high temperature, drought and saline conditions suggests that they may be promising candidates for use as biocontrol agents.

\section{Acknowledgements}

This study was supported by the Harran University Research Foundation (Project No: 16207).

\section{Conflict of Interest}

All authors declare that: there are no other relationships or activities that could appear to have influenced the submitted work. 


\section{Authors Contribution}

TG (Post Graduate Student) conducted experiments and recorded observations, data analysis and references, conducted manuscript proofreading before submission. ÇK (Professor of Microbiology) conceived the idea, about the laboratory technique and supervised the experiment and wrote the concept and discussion. All authors read and approved the final version of the manuscript.

\section{References}

Abdel-Latif, H., \& Haggag, W. M. (2005). Biocontrol potential of salinity tolerant mutants of Trichoderma harzianum against Fusarium oxysporum causing tomato wilt disease. Arab Journal of Biotechnolohgy. 8 (1), 35-48. https://doi.org/10.1590/S151783822006000200016

Alamri, A., Mostafa, Y.S., Hashem, M., \& Alrumman, S. (2015). Enhancing the biocontrol efficiency of Trichoderma harzianum JF419706 through cell Wall degrading enzyme production. International Journal of Agriculture and Biological Sciences, 18 (4), 765-772. http://www.fspublishers.org/published_papers/16674_..pdf

Amalraj, L. D., Kumar, P., Desai, S., \& Akmed, M. H. (2010). In vitro Characterization of Trichoderma viride for abiotic stress tolerance and field evaluation against root rot disease in Vigna mungo L. Journal of Biofertility \& Biopesticides, 2 (3), 2-5.

https://doi.org/10.4172/2155-6202.1000111

Begoude, B. A. D., Lahlali, R., Friel, D., Tondje, P. R., \& Jijakli, M. H. (2007). Response surface methodology study of the combined effects of temperature, $\mathrm{pH}$, and aw on the growth rate of Trichoderma asperellum. Journal of Applied Microbiology, 103 (4), 845854. https://doi.org/10.1111/i.13652672.2007.03305.X

Bradford, M. M. (1976). A rapid and sensitive method for the quantitation of microgram quantities of protein utilizing the principle of protein-dye binding. Analytic of Biochemistry, 72 (1-2), 248-254. https://doi.org/10.1016/0003-2697(76)90527-3

Btaszcyk, L., Siwulski, M., Sobieralski, K., Lisiecka, J., \& Jedryczka, M. (2014). Trichoderma Spp.-application and prospects for use in organic farming and industry. Journal of Plant Protection Research, 54 (1), 310-317. https://doi.org/10.2478/jppr-2014$\underline{0047}$
Ferre, F. S., \& Santamarina, M. P. (2010). Efficacy of Trichoderma harzianum in suppression of Fusarium culmorum. Annals of Microbiology, 60 (2), 335-340. https://doi.org/10.1007/s13213-010-0047-y

Gajera, H. P. \& Vakharia, D. N. (2012). Production of lytic enzymes by Trichoderma isolates during in vitro antagonism with Aspergillus niger, the causal agent of collar rot of peanut. Brazilian journal of Microbiology, 43 (1), 43-52. https://doi.org/10.1590/S1517$\underline{83822012000100005}$.

Ghanbarzadeh, B., Safaie, N., \& Goltapeh, E. M. (2014). Antagonistic activity and hyphal interactions of Trichoderma spp. against Fusarium proliferatum and F.oxysporum in vitro. Journal Archives of Phytopathology and Plant Protection, 47 (16), 17891987.

https://doi.org/10.1080/03235408.2013.864506

Karmel-Reetha, A., Pavani, S. L., \& Mohan, S. (2014). Ecofriendly management of fungal antagonistic Trichoderma sp. against charcoal rot of sunflower caused by Macrophomina phaseolina (Tassi) Goid. Journal of Biopesticides, 7 (1), 73-76. http://www.jbiopest.com/users/LW8/efiles/vol 7 1_73-76.pdf

Kumari, R., Shekhawat, K. S., Gupta, R., \& Khokhar, M. (2012). Integrated management against root-rot of mungbean (VignarRadiata (L.) Wilczek) indiced by Macrophomina phaseolina. Journal of Plant Pathology and Microbiology, 3 (5), 136.

https://www.longdom.org/open-access/integrated-management-against-root-rot-of-mungbean-vigna-radiata-l-wilczek-incited-by-macrophomina-phaseolina-2157-7471.1000136.pdf

Lopez-Mondejar, R., Ros, M., \& Pascual, J. A. (2011). Mycoparasitism-related genes expression of Trichoderma harzianum isolates to evaluate their efficacy as biological control agent. Biological Control, 56 (1), 59-66. https://doi.org/10.1016/i.biocontrol.2010.10.003

Lorito, M., Woo, S. L., Harman, G. E., \& Monte, E. (2010). Translational research on Trichoderma: from, omics to the field. Annual of Review Phytopathology, 48 (1), 234-246. https://doi.org/10.1146/annurevphyto-073009-114314

Mendoza, J. L. H., Pérez, M. I. S., Prieto, J. M. G., Velásquez, J. D. Q., Olivares, J. J. G., \& Langarica, H.G.R. (2015). Antibiosis of Trichoderma spp strains native to northeastern Mexico against the pathogenic fungus Macrophomina phaseolina. Brazilian Journal of Microbiology, 46 (4), 1093- 1101. 
https://doi.org/10.1590/S1517-

838246420120177.

Mishra, N., Khan, S. S., \& Sundari, S. K. (2016). Native isolate of Trichoderma: a Biocontrol agent with unique stress tolerance properties. World Journal of Microbiology \& Biotechnology, 32 (8), 130-153.

https://doi.org/10.1007/s11274-016-2086-4

Mohammed, H., \& Haggag, W. M. (2006). Biocontrol potential of salinity tolerant mutants of Trichoderma harzianum against Fusarium oxysporum. Brazilian Journal of Microbiology, 37 (2), 35-48.

https://doi.org/10.1590/S1517$\underline{83822006000200016}$

Mukherjee, P. K., \& Raghu, K. (1997). Effect of temperature on antagonistic and biocontrol potential of Trichoderma sp. on Sclerotium rolfsii. Mycopathology, 139 (3), 151-155.

https://doi.org/10.1023/A:1006868009184

Nikolajeva, V., Petrina, Z., Vulfa, L., Alksne, L., Eze, D., Grantina, L., Gaitnieks, T., \& Lielpetere, A. (2012). Growth and antagonism of Trichoderma spp. and conifer pathogen Heterobasidion annosums. in vitro at different temperatures. Advanced of Microbiology, 2 (3), 295-302.

http://dx.doi.org/10.4236/aim.2012.23035

Poosapati, S., Ravulapalli, P. D., Tippirishetty, N., Vishwanathaswany, D. K., \& Chunduri, S. (2014). Selection of high temperature and salinity tolerant Trichoderma isolates with antagonistic activity against Sclerotium rolfsii. SpringerPlus, 3 (1), 641652. https://doi.org/10.1186/2193-1801-3-641

Qualhato, F. T., Lopes, F. A. C., Steindorff, A. S., Brandao, R. S., Jesuino, R. S. A., \& Ulhoa, C. J. (2013). Mycoparasitism studies of Trichoderma species against three phytopathogenic fungi: evaluation of antagonism and hydrolytic enzyme production. Biotechnology Letters, 35 (9), 1461-1468.

https://doi.org/10.1007/s10529-013-1225-3

Rao, K. L. N. M., Raju, K. S., \& Ravisankar, H. (2015). Antifungal properties of native Trichoderma isolates against Sclerotium rolfsii and Pythium apha-

nidermatum infecting tobacco. Journal of Environ-

mental Biology, 36 (6), 1349- 1353. PMID:

26688972

Regragui, A., \& Lahlou, K. (2005). Effect of salinity on in vitro Trichoderma harzianum Antagonism Against Verticillium dahliae. Pakistan Journal of Biological Sciences, 8 (6), 872-876.

http://dx.doi.org/10.3923/pjbs.2005.872.876

Reetha, A. K., Ravani, S. L., \& Mohan, S. (2014). Ecofriendly management of fungal antagonist Trichoderma sp. against charcoal rot of sunflower caused by Macrophomina phaseolina (Tassi) Goid. Journal of Biopesticides, 7 (1), 73-76. http://www.jbiopest.com/users/LW8/efiles/vol 7 1173-76.pdf

Rey, M., Delgado-Jarana, J., \& Benítez, T. (2001). Improved antifungal activity of a mutant of Trichoderma harzianum CECT 2413 which produces more extracellular proteins. Applied of Microbiology \& Biotechnology, 55 (1), 604-608.

https://doi.org/10.1007/s002530000551.

Schuster, A., \& Schmoll, M. (2010). Biology and Biotechnology of Trichoderma. Applied of Microbiology and Biotechnology, 87 (3), 787-799.

https://doi.org/10.1007/s00253-010-2632-1

Srivastova, M., Shahid, M., Pandey, S., Kumar, V., singh, A., Trivedi, S., \& Srivastova, Y. K. (2015). Trichoderma: A scientific approach against soil borne pathogens. African Journal of Microbiology Research, 9 (50), 2377-2384.

https://doi.org/10.5897/AJMR2015.7788

Szekeres, A., Kredics, L., Antal, Z., Kevei, F., \& Manczinger, L. (2004). Isolation and characterization of protease overproducing mutants of Trichoderma harzianum. FEMS Microbiology Letters, 233 (2), 215-222. https://doi.org/10.1111/j.1574$\underline{\text { 6968.2004.tb09485.x }}$ 